Jpn. J. Oral Biol., 41 : 11-20, 1999.

\title{
ORIGINAL
}

\section{Ultrastructures of the Sublingual and Interpapillar Surfaces of the Human Tongue}

\author{
Michiyo Kuwahara, Kikuji Yamashita*, Youji Miyamoto**, \\ Fumio Nasu and Hiroshi Ishizuka \\ Second Department of Oral Anatomy, School of Dentistry, The University of Tokushima \\ *First Department of Oral Anatomy, School of Dentistry, The University of Tokushima \\ **First Department of Oral and Maxillofacial Surgery, School of Dentistry, The University of Tokushima \\ 3-18-15, Kuramoto-cho, Tokushima 770-8504, Japan
}

(Received on August 24, 1998 ; Accepted on November 25, 1998]

Key words: human tongue/ultrastructure/sublingual epithelium/interpapillar epithelium/microridge

\begin{abstract}
The fine structures of the sublingual and interpapillar surfaces of the human tongue were examined by light microscopy, and scanning and transmission electron microscopies. After consent, specimens of the normal median area of the tongue were obtained during surgery. The patterns of microridges on the sublingual and interpapillar epithelial surfaces were similar, but the structure of the longitudinal sections of microridges in the sublingual and interpapillar epithelial cells differed. Long microridges with many branches were abundant in the sublingual area, but from the lingual apex to the lingual body, the proportion, height and number of microridge branches of interpapillar epithelial cells gradually decreased. The width of the interpapillar epithelial cell microridges was least in the lingual apex. The differences in microridge shape between the sublingual and interpapillar epithelial cells may be related to differences in retention of mucus, cell stretching and mechanical forces, reflecting the functions of the respective regions.

抄録：ヒト舌の舌下面の上皮と舌背の舌乳頭間上皮の表面構造を光学顕微鏡, 走査型ならびに透過型電子顕微 鏡で観察した。患者の同意を得て, 外科手術で摘出した健康なヒト舌中央部を試料とした。観察の結果, 舌下面 の上皮と舌背の舌乳頭間上皮では, 表面の微小堤のパターンは類似していたが, 微小堤の綐断像の構造は部域に より異なっていた。すなわち, 舌下面では多くの分岐を伴った長い微小堤が豊富に存在したが, 舌尖から舌体に かけては舌乳頭間上皮細胞の微小堤の密度や高さ, 分岐の数が減少した。微小堤の幅は舌尖で最も小さかった。 このような舌下面の上皮と舌背の舌乳頭間上皮の表面の微小堤の形態の違いは, 各部域の機能を反映すると考え られ, 粘液保持, 細胞の伸展, 機械的な力の違いと関連することが推察された。
\end{abstract}

\section{Introduction}

The structure of the oral mucous membrane varies in relation to function in different regions of the oral cavity ${ }^{1}$. The ridge-like folds on the surface of epithelial cells in the oral mucous membrane, known variously as microridges and microplicae, have been studied by scanning electron microscopy ${ }^{2-6}$. In these studies, the patterns of the microridges in mammalian species are reported to be similar in different regions of the oral mucous epithelia, except those of the keratinized epithelia which have a pitted appearance. However, some differences in the surface features of 
the microridges in different regions of the oral cavity have been reported ${ }^{4}$, and their structures, reflecting functional differences in different regions of the oral cavity, are not yet clear.

The tongue consists of functionally different oral mucosae. The mucosa of the inferior surface of the tongue is covered by a lining mucosa, while that of the dorsal surface is covered by a specialized mucosa that is functionally a masticatory mucosa ${ }^{7}$. The anterior part of the dorsal surface of the tongue is covered by filiform and fungiform papillae. Filiform papillae are involved in compressing and breaking up food, functioning as masticatory mucosa. Single fungiform papillae are scattered between the filiform papillae and the tip of the tongue. Thus, the sublingual area, the lingual apex and the lingual body were considered to have functional differences.

The detailed microridge structures in these areas of the tongue are not clear. The structure of the tongue epithelium of animals has been studied by scanning electron microscopy ${ }^{8-14)}$. The dorsum of the tongue has some lingual papillae and interpapillar epithelium. The surface of the sublingual and interpapillar epithelium has more distinct microridges than that of the keratinized lingual papillae, but the detailed microridge structures of the sublingual and interpapillar epithelium are unclear. Observations of the normal human tongue have been reported ${ }^{5,15,16}$. However, these studies were on limited areas and did not include the ventral surface of the tongue. In particular, there have been few studies on the interpapillar epithelium. One reason for this is that it is difficult to obtain specimens of normal human tongue. However, studies on the structure of normal human tongues are important for understanding the normal structure of microridges as reflected in their functional differences in different regions of the oral cavity.

Therefore, in the present study we examined details of the structure of the sublingual and interpapillar epithelium of the median area of normal human tongues, and characterized the microridge structures in each area. The explanation for the presence of microridges is controversial. They have been sug. gested to be nonfunctional remnants of the connection between the superficial epithelial cells of the stratified squamous epithelium, but their functional roles have also been put forward ${ }^{4,17}$. Here the functions of microridges, reflecting functional differences in these areas, are discussed based on our findings.

\section{Materials and Methods}

The median areas from the sublingual to the dorsal region of normal tongues were obtained during reduction of the tongue by orthognathic surgical procedure. They were examined with patient and parental consent. The specimens were promptly washed with a soft brush to remove mucus. The sublingual area (SA), the lingual apex (LA) and the lingual body (LB) of each part was examined visually (Figs. 1,2) .

Specimens from 13-, 14- and 23-year-old females were used for light and scanning electron microscopic studies. For light microscopic studies, specimens were cut into three parts (SA, LA, LB), and fixed in 10\% formaldehyde in $0.1 \mathrm{M}$ phosphate buffer $(\mathrm{pH} \mathrm{7.4)}$ for 5 days. The fixed tissues were processed routinely and stained with hematoxylin and eosin. For scanning electron microscopy (SEM), the specimens were cut into three parts (SA, LA, LB), and fixed in $2.5 \%$ glutaraldehyde in $0.1 \mathrm{M}$ phosphate buffer $(\mathrm{pH} 7.4)$ for $4 \mathrm{~h}$ at $4^{\circ} \mathrm{C}$. Then, they were washed in $0.1 \mathrm{M}$ phosphate buffer and post-fixed in $2 \%$ osmium tetroxide in $0.1 \mathrm{M}$ phosphate buffer for $1 \mathrm{~h}$ at $4^{\circ} \mathrm{C}$, dehydrated in a graded ethanol series, and immersed in isoamyl acetate. After critical point drying, the specimens were mounted on aluminum studs, coated with gold $(200 \AA)$, and examined with a Hitachi S-700 scanning electron microscope at $20 \mathrm{kV}$.

For transmission electron microscopy (TEM), a specimen from a 23-year-old female was used. Each part of the tongue was cut into small blocks and fixed in $2.5 \%$ glutaraldehyde in $0.1 \mathrm{M}$ phosphate buffer $(\mathrm{pH} 7.4)$ for $4 \mathrm{~h}$ at $4^{\circ} \mathrm{C}$. Then the samples were washed in a $0.1 \mathrm{M}$ phosphate buffer, post-fixed in $2 \%$ osmium tetroxide in $0.1 \mathrm{M}$ phosphate buffer for $1 \mathrm{~h}$ at $4^{\circ} \mathrm{C}$, dehydrated in an ethanol series, immersed in n-butyl glycidyl, and embedded in Epon 812. Epon blocks were sectioned with an LKB Ultrotome $\mathrm{V}$ and sections were collected on formvar- and carbon-coated singlehole grids. Ultrathin sections were double-stained 
with uranyl acetate and lead citrate and examined with a Hitachi $\mathrm{H}-800$ transmission electron microscope.

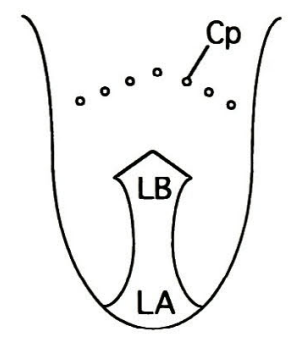

A

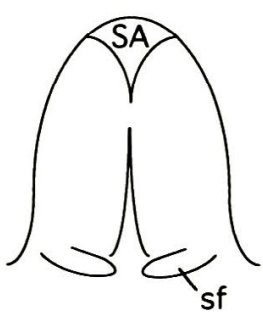

B
Fig. 1 Diagram of the surface of the human tongue.

A : Dorsal surface of the tongue. The lingual apex (LA) and the lingual body (LB) are indicated.

$B$ : Ventral surface of the tongue. The sublingual area (SA) is indicated.

$\mathrm{Cp}=$ circumvallate papilla, $\mathrm{sf}=$ sublingual fold.
For measurement of the microridge structures, transmission electron micrographs of each region at a magnification of 30,000 were traced. The areas of the microridges from the baseline were measured with a digitizer (Fig. 3). The heights of perpendicular lines from the tips of single or branched microridges to the baseline were measured with a digitizer (Fig. 3). All measurements were made in triplicate. The width was calculated as the area divided by the height. The total height was used in the calculation of the width of branched microridges. The means of triplicate measurements and unbiased estimates of standard deviations were obtained. After an F-test for equality of variances, the heights and widths in each region were compared using a Student's t-test or Welch's t-test taking a $\mathrm{p}<0.05$ level as significant. Microridge numbers were assessed by counting microridge tips. The baseline lengths between points where the cell surface and the baseline intersected and those of cell surfaces

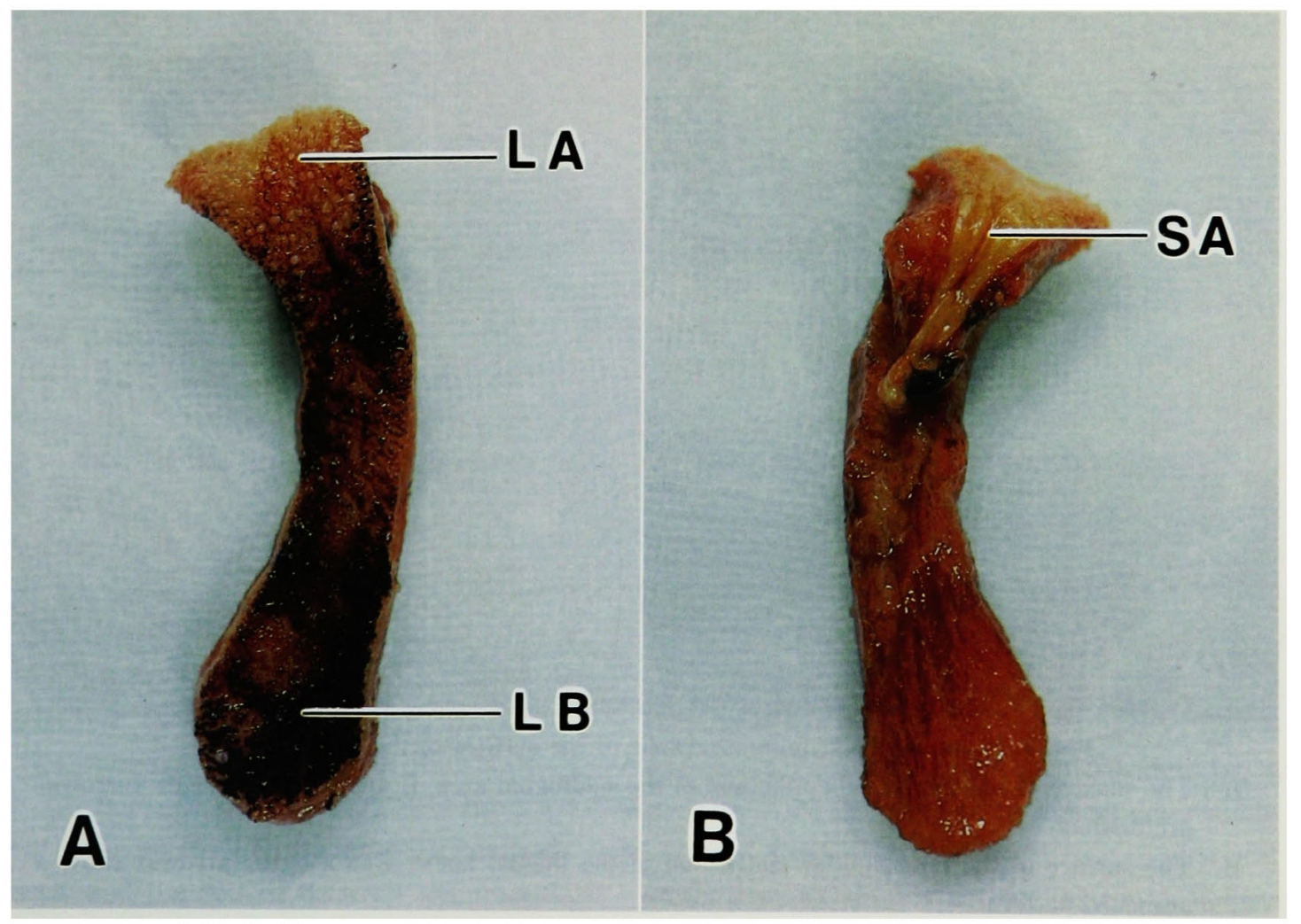

Fig. 2 Macroscopic photographs of the central area of the human tongue.

A : View of the dorsal surface. The lingual apex (LA) and the lingual body (LB) are indicated.

$B$ : View of the ventral surface. The sublingual area (SA) is indicated. 
that had no microridges were measured in triplicate. The rate of microridge occupation was evaluated as the number of microridges per $1 \mu \mathrm{m}$ length. The total
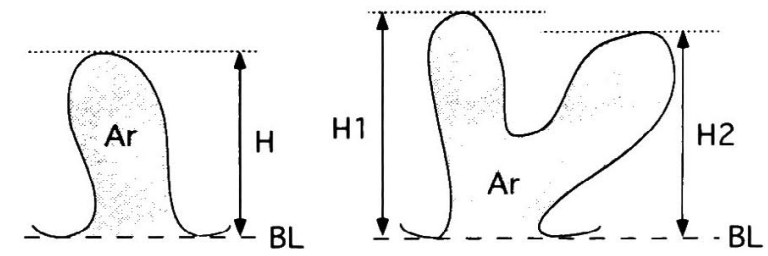

A

B

Fig. 3 Diagram of measurement of microridges.

A : A single microridge.

B : Branched microridge. Height 1 (H 1) and height 2(H 2) indicate the total height.

$\mathrm{Ar}=$ area of microridge, $\mathrm{BL}=$ baseline, $\mathrm{H}=$ height of microridge number of microridges and the microridge area at each site were calculated.

\section{Results}

\section{Light microscopy}

The epithelia of the sublingual area (SA), the interpapillar epithelia of the lingual apex (LA) and the lingual body (LB) were not keratinized. These findings are consistent with a previous report ${ }^{7}$. The salivary duct opened onto the surface of the epithelium in the sublingual area (SA).

\section{Scanning electron microscopy}

The surfaces of interpapillar epithelial cells were seen to be covered by microridges. The microridges in

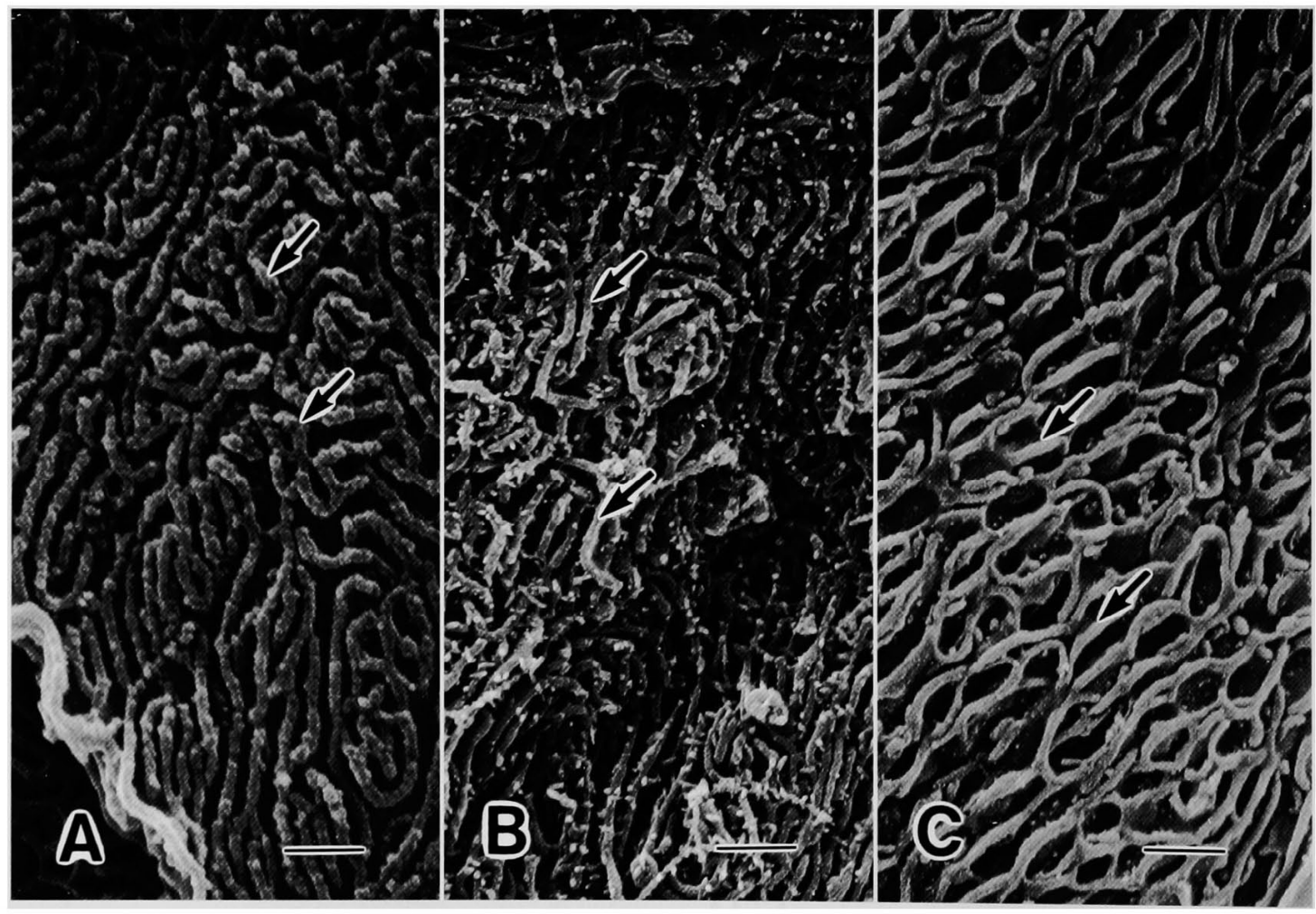

Fig. 4 Scanning electron micrographs of the surface of the human tongue.

A : The surface of the sublingual epithelium of the sublingual area. Branched microridges (arrows) are distinct

B : The surface of the interpapillar epithelium of the lingual apex. Microridges (arrows) show a branched pattern.

$\mathrm{C}$ : The surface of the interpapillar epithelium of the lingual body. Branched microridges (arrows) show a slightly indistinct pattern.

Bars $=1 \mu \mathrm{m}$ 


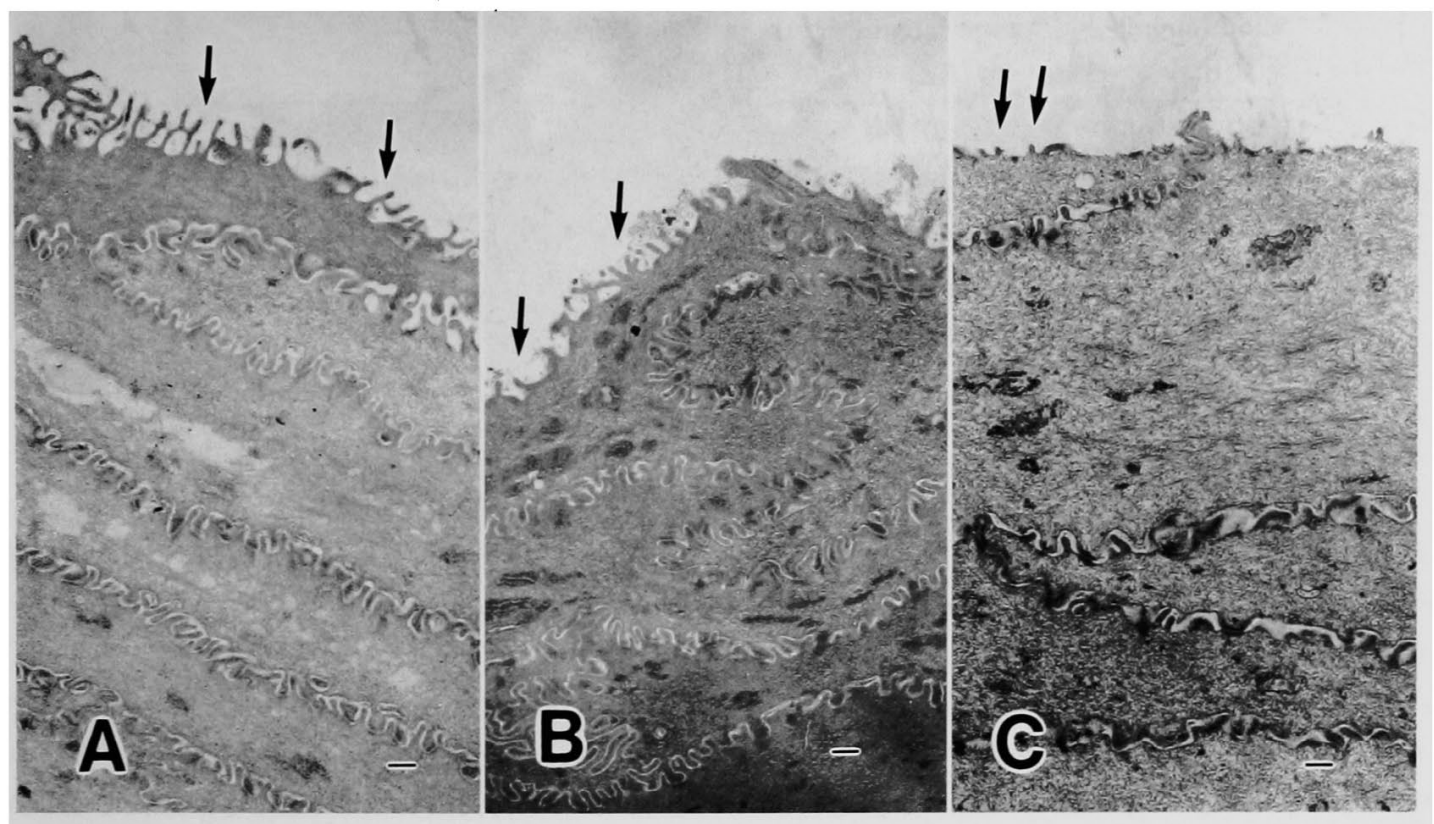

Fig. 5 Transmission electron micrographs of the superficial layers of the sublingual epithelium of the sublingual area (A), and the interpapillar epithelium of the lingual apex (B) and the lingual body (C).

A : Microridges (arrows) are high and numerous. Branched tips of microridges are seen.

B : Microridges (arrows) are lower than those in the sublingual area.

$\mathrm{C}:$ Microridges (arrows) are lower than in the lingual apex. There are fewer microridges.

Bars $=0.5 \mu \mathrm{m}$

each area showed parallel or branching patterns. In the SA and LA, microridges were distinct (Fig. $4 \mathrm{~A}$, $B$ ). In the LB, the microridges were slightly indistinct and interrupted (Fig. $4 \mathrm{C}$ ), and the spaces between the microridges were wider than in the SA and the LA (Fig. 4).

\section{Transmission electron microscopy}

At low magnification, microridges of the interpapillar epithelial cells were observed as tips of various shapes. In longitudinal sections of the SA, microridges were congested and their tips were often branched (Fig. $5 \mathrm{~A}$ ). The microridges were not as high in the LA as in the SA. Some of the microridges in the LA branched (Fig. 5 B). In the LB, the microridges had small processes, and the spaces between the microridges were relatively wide (Fig. $5 \mathrm{C}$ ). These characteristics were clearly seen at higher magnifications (Figs. 6, 7).
The microridge characteristics in each area were documented by analysis of surface structures (Table 1). The microridge heights gradually decreased from the SA to the LB. The difference in height of microridges in the SA and LB was significant $(p<0.05)$. The microridge heights in the LA and other regions were not significantly different. The width of microridges was least in the LA, and was greater in the LB than in the SA. The widths were significantly different $(p<0.05)$ by Student's $t$-test in the SA and LB, and in the SA and LA, and by Welch's $\mathrm{t}$-test in the LA and LB. The fewest microridges were found in the LB. The number of microridges per area decreased from the SA to the LB as determined by their total numbers and areas.

In the superficial layer, intercellular interdigitations showed some similar features to microridges (Fig. 5, 6). They were long, branched and abundant in the $S A$ and LA, but short and scarce in the LB. In the LB, the 


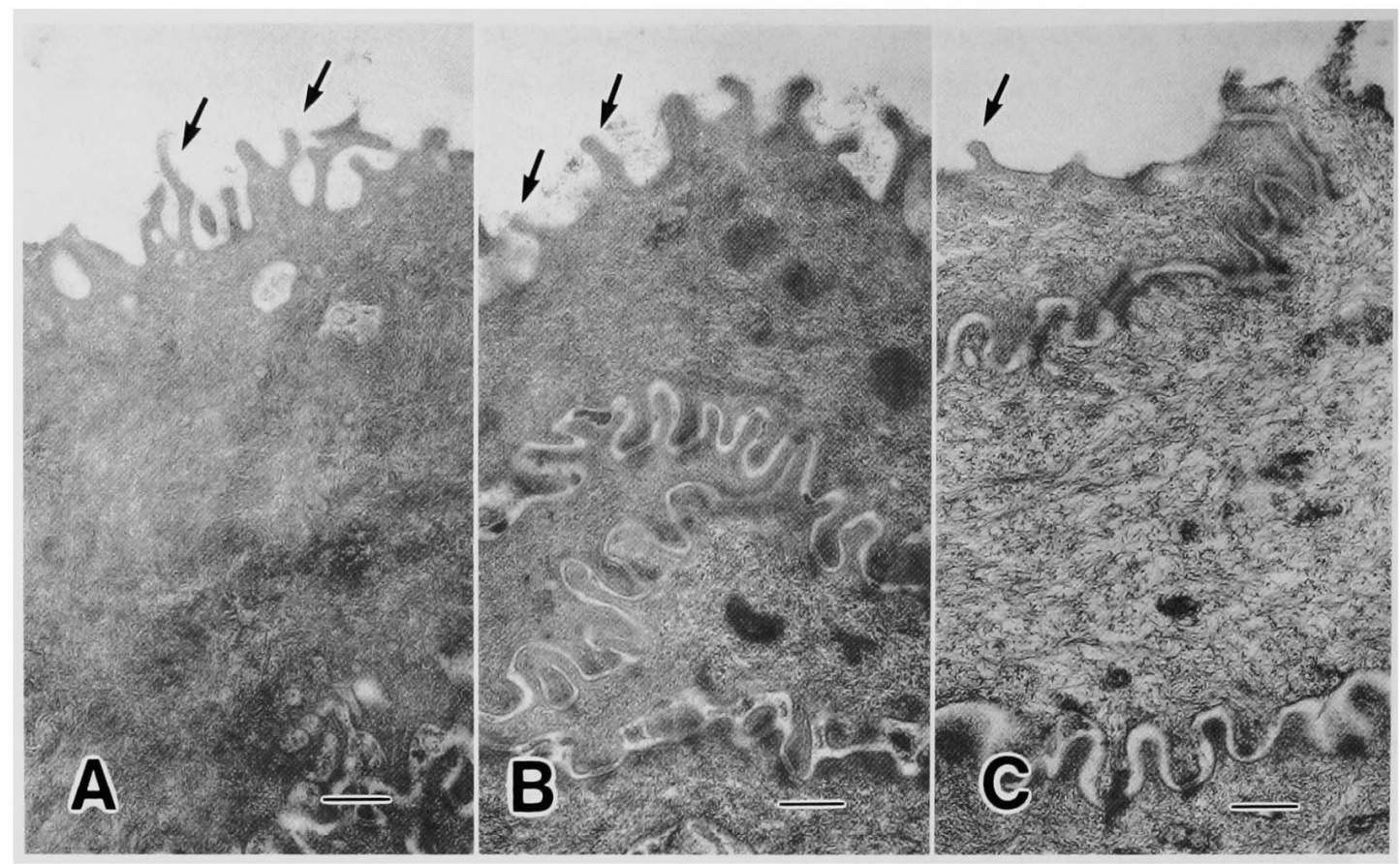

Fig. 6 Higher magnifications of transmission electron micrographs of the surfaces of the sublingual epithelium of the sublingual area (A), and the interpapillar epithelium of the lingual apex (B) and the lingual body $(\mathrm{C})$.

Desmosomes can be seen between intercellular interdigitations. Filaments in the superficial cells are sparse and roughly parallel to the cell surface in $\mathrm{C}$.

Arrows $=$ microridges, Bars $=0.5 \mu \mathrm{m}$

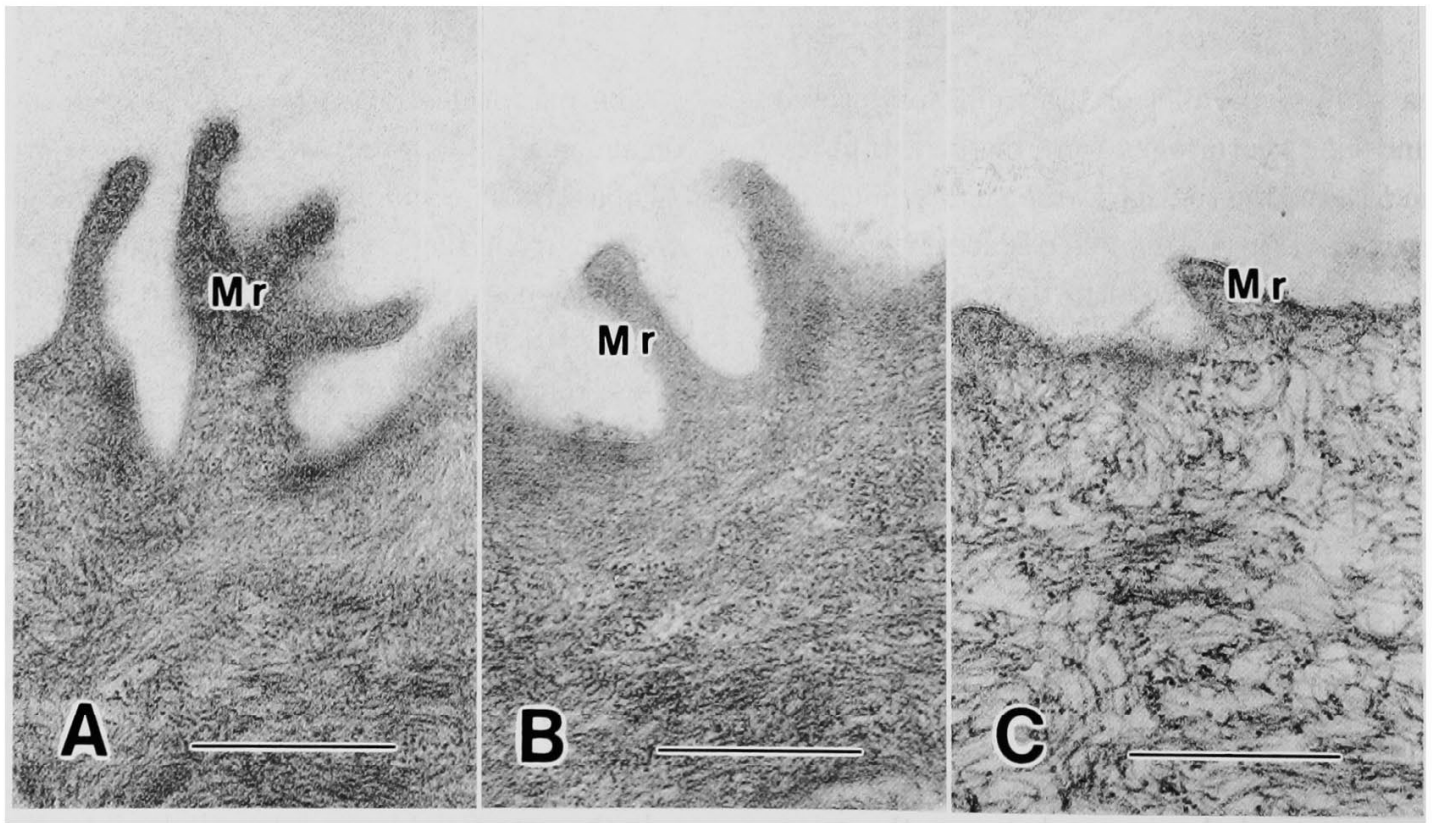

Fig. 7 Higher magnifications of transmission electron micrographs of microridges.

Surfaces of the sublingual epithelium of the sublingual area (A), and the interpapillar epithelium of the lingual apex (B) and the lingual body (C).

$\mathrm{Mr}=$ microridge, Bars $=0.5 \mu \mathrm{m}$ 
Table 1 Height, width and number of microridges

\begin{tabular}{lccc}
\hline & $\begin{array}{c}\text { sublingual area } \\
(\mathrm{SA})\end{array}$ & $\begin{array}{c}\text { lingual apex } \\
(\mathrm{LA})\end{array}$ & $\begin{array}{c}\text { lingual body } \\
(\mathrm{LB})\end{array}$ \\
\hline mean height in $\mu \mathrm{m}(\mathrm{SD})$ & $0.421(0.1618)^{*}$ & $0.400(0.1628)$ & $0.340(0.1622)^{*}$ \\
mean width in $\mu \mathrm{m}(\mathrm{SD})$ & $0.165(0.0539)^{*}$ & $0.149(0.0420)^{*}$ & $0.233(0.0665)^{*}$ \\
\hdashline number $/ \mu \mathrm{m}$ & 1.471 & 1.452 & 0.835 \\
\hdashline total number of microridges & 132 & 138 & 34 \\
total number of areas of & 93 & 109 & 30 \\
microridges & & & \\
\hline${ }^{*} \mathrm{p}<0.05$ & & &
\end{tabular}

intercellular interdigitations had more processes than the microridges. The superficial cells of the LB exhibited a sparse array of filaments (Fig. 6,7). Some filaments in the superficial cells of the LB were arranged parallel to the cell surface (Fig. 6). Desmosomes were frequently observed between the intercellular interdigitations in each area (Fig.6).

\section{Discussion}

The microridge patterns have been studied by scanning electron microscopy in the interpapillar epithelium of the tongue and the non-keratinized epithelia of the soft palate, cheek, lip and floor of the human oral cavity, and have all been found to have parallel or branching patterns ${ }^{5,6,15,17)}$. In this study too, we found that the microridges on the sublingual and interpapillar surfaces of each area of the human tongue showed parallel or branching patterns. However, we found using scanning electron microscopy that the microridges on the interpapillar surface in the lingual body showed slightly different characteristics. They were rather indistinct, and the spaces between the microridges were wide.

The structures of longitudinal microridge sections in the interpapillar epithelium of animals have been observed by transmission electron microscopy and seen to have fine processes ${ }^{14,18-21)}$, but their detailed structures have not been reported. In the present study, we found that the structures of microridges in the sublingual and interpapillar epithelium of the human tongue are different. The microridges of the sublingual area are well developed, but those of the dorsal surface gradually shrink from the apex toward the lingual body. These findings are consistent with the slight differences in the microridges in the lingual body observed by scanning electron microscopy. The total number of microridges is greater than the microridge area, indicating an increase in branched microridges as shown in Table 1. The results in Table 1, and those generated by transmission electron microscopy, suggest that microridges tend to branch toward the SA. These differences are related to the functions of these regions.

The microridges on the free surface of epithelial cells have been suggested to be remnants of intercellular interdigitation and adhesion between cells ${ }^{2,3,22-26)}$. In the present study, intercellular interdigitations showed similar features to microridges and desmosomes were observed between them. These observations indicate that the microridges represent the same plasmalemma folds that once provided for intercellular interdigitation and adhesion. The adhesion potential may not be related to regional differences because the distribution and number of desmosomes were similar in each area. However, we found that in the lingual body the microridges on the free surface were fewer than the intercellular interdigitations. This suggests that the microridges may also have functions which reflect functional differences in different regions.

Several hypotheses have been proposed for the functional roles of microridges on the cell surface. One is that they may play a role in holding mucus to protect the epithelium ${ }^{27)}$. Salivary ducts were seen in the sublingual area in our study. Microridges were 
especially well developed in this area, and thus were thought to function in retaining and gradually supplying mucus, especially in the sublingual area. Microridges on the lingual apex were an intermediate type between those of the lingual body and the sublingual area. The narrow width of medium height microridges may be useful for retaining mucus. The microridges in the sublingual area and the lingual apex may also play a role in retaining mucus.

Wassersug and Johnson ${ }^{28)}$ suggested that microridges may represent a reserve of surface area for cell stretching. However, this hypothesis is not consistent with the report of Sperry and Wassersug ${ }^{27}$. They studied microridges in unstretched and stretched conditions in fish (Salmo gairdneri) esophageal mucosae, and they found no change in appearance between the microridges in the two conditions. On the other hand, Grossman and Austin ${ }^{29)}$ found that loading produced flattening of cells throughout the epithelium in the oral mucosa of the vervet monkey. They reported some decrease in cellular width in the superficial cells in response to loading in the non-keratinized alveolar and buccal mucosae. The present study suggests that the dense microridges of the sublingual area may play a role as a reserve for stretching the surface area, while the low number of lingual body microridges do not. The few lingual body microridges may protect superficial cells from too much transformation by continuous mechanical forces (compression, stretching, shearing) during mastication.

Microridges may also provide protection by reducing the surface area of contact and thereby minimizing frictional resistance between opposing surfaces and by holding mucus as a cushioning layer ${ }^{28,30-31}$. However, Iwasaki and Miyata ${ }^{32}$, Iwasaki and Sakata ${ }^{10)}$, Iwasaki et al. ${ }^{11)}$ and Iwasaki et al. ${ }^{12)}$ concluded that microridges are not necessarily an adaptation to friction, because there is strong friction on the lingual surface of keratinized filiform papillae which do not have clear microridges. They thought that microridges may appear in the course of keratinization. In our study, we found that the interpapillar epithelium in the lingual body had rough, low microridges and was not keratinized as determined by light microscopy. Our results suggest that microridges in non- keratinized epithelium do not reduce frictional forces by reducing the surface area of contact or holding mucus as a cushioning layer.

We conclude from this work that there may be a close relationship between the structure of microridges and the functions of the sublingual and interpapillar epithelia of the human tongue. Though the microridges may be the remnants of connections between epithelial cells, they may also have functional roles that reflect functional differences between sites. The effect of mechanical forces on the surface of nonkeratinized interpapillar epithelium is still unknown. Sparse, parallel arrays of filaments were observed in the interpapillar surface cells in the lingual body in our study. Uehara et al. ${ }^{33,34)}$ observed that actin filaments in oral mucosal epithelium microridges in the carp (Cyprinus carpio) connected to the keratin filaments that underlay the network of actin filaments. We speculate that mechanical forces on the lingual body may result in alteration of the cytoskeleton and formation of rough, low microridges. Further investigation into the relationship between mechanical forces and functions of the microridges are necessary. Our findings should be helpful in understanding the mechanism of protection of non-keratinized oral epithelium in humans.

\section{References}

1) Bhaskar, S.N. : Orban's Oral histology and embryology. 11 th ed., pp. 260-336, Mosby-Year Book, Inc. St.Louis, 1991.

2) Cleaton-Jones, P. and Fleisch, L. : A comparative study of the surface of keratinized and non-keratinized oral epithelia. J. Periodontal Res. $8: 366-370$, 1973.

3) Appleton, J. and Heaney, T.G. : A scanning electron microscope study of the surface features of porcine oral mucosa. J. Periodontal Res. $12: 430-435,1977$.

4) Nair, P.N.R. and Schroeder, H.E. : Variation and density of microplications in superficial cells of the normal oral lining mucosa in the monkey Macacus fascicularis. Archs Oral Biol. 26 : 837-843, 1981.

5) El Zoghby, S. and Moussa, M. : Regional variations of the normal oral mucosa : a study by scanning electron microscopy. Egypt. Dent. J. 32:39-56, 1986. 
6) Kullaa-Mikkonen, A.: Scanning electron microscopic study of surface of human oral mucosa. Scand. J. Dent. Res. 94:50-56, 1986.

7) Ten Cate, A.R. : Oral histology : development, structure, and function. 4 th ed., pp. 389-431, Mosby-Year Book, Inc. St.Louis, 1994.

8) Aufdemorte, T.B. and Cameron, I.L. : The relation of keratinization to bacterial colonization on the baboon tongue as demonstrated by scanning electron microscopy. J. Dent. Res. 60 : 1008-1014, 1981.

9) Iwasaki, S., Miyata, K., Mori, H., Sakata, K. and Kobayashi, K. : Fine structure of the lingual dorsal surface in rats. Kaibogaku Zasshi $59:$ 18-27, 1984. (in Japanese)

10) Iwasaki, S. and Sakata, K. : Scanning electron microscopy of the lingual dorsal surface of the beagle dog. Okajimas Folia Anat. Jpn. 62:1-13, 1985.

11) Iwasaki, S., Miyata, K. and Kobayashi, K. : Comparative studies of the dorsal surface of the tongue in three mammalian species by scanning electron microscopy. Acta Anat. (Basel) $128: 140-146,1987$.

12) Iwasaki, S., Miyata, K. and Kobayashi, K.: The surface structure of the dorsal epithelium of tongue in the mouse. Kaibogaku Zasshi $62: 69-76,1987$.

13) Chunhabundit, P., Thongpila, S. and Somana, R. : SEM study on the dorsal lingual surface of the common tree shrew, Tupaia glis. Acta Anat. (Basel) $143: 253-257,1992$.

14) Iwasaki, S., Yoshizawa, H. and Suzuki, K. : Fine structure of the dorsal lingual epithelium of the Japanese monkey Macaca fuscata fuscata. Acta Anat (Basel) 144:267-277, 1992.

15) Kullaa-Mikkonen, A. and Sorvari, T.E. : A scanning electron microscopic study of the dorsal surface of the human tongue. Acta Anat. (Basel) 123 : $114-120,1985$.

16) Kullaa-Mikkonen, A., Hynynen, M. and Hyvönen, P. : Filiform papillae of human, rat and swine tongue. Acta Anat. (Basel) $130: 280-284,1987$.

17) Kullaa-Mikkonen, A. : Scanning electron microscopy in oral mucosal research : a review. Scanning Microsc. 1 : 1145-1155, 1987.

18) Iwasaki, S. and Miyata, K. : Light and transmission electron microscopic studies on the lingual dorsal epithelium of the musk shrew, Suncus murinus. Okajimas Folia Anat. Jpn. 62:67-88, 1985.

19) Iwasaki, S. and Miyata, K. : Fine structure of the filiform papilla of the beagle dogs. J. Morphol. 201 :
235-242, 1989.

20) Iwasaki, S., Miyata, K. and Kobayashi, K. : Fine structure of the epithelial cells of the lingual dorsal mucosa in the guinea pig. Kaibogaku Zasshi 64 : 109-125, 1989. (in Japanese)

21) Iwasaki, S. and Miyata, K. : Fine structure of the dorsal epithelium of the mongoose tongue. J. Anat. 172:201-212, 1990.

22) Cleaton-Jones, P.: Surface ultrastructure of the mucosa of the soft palate in the vervet monkey. S. Afr. J. Med. Sci. 37 : 101-104, 1972.

23) Cleaton-Jones, P.: Surface characteristics of cells from different layers of keratinized and non-keratinized oral epithelia. J. Periodontal Res. 10: 79-87, 1975.

24) Cleaton-Jones, P., Buskin, S.A. and Volchansky, A. : Surface ultrastructure of human gingiva. J. Periodontal Res. 13:367-371, 1978.

25) Hodgkins, J.F.W., Watkins, R. and Walker, D.M. : Correlated scanning and transmission electron microscopy of cell surfaces at various levels in the human gingival epithelium. Arch Oral Biol. 23 : 355-360, 1978.

26) Saito, H., Takagi, T. and Nozaka, Y.: The ultrastructure of the cell surface of the miniature pig's oral epithelium with special reference to microridges. Jpn. J. Oral Biol. 24:406-417, 1982. (in Japanese)

27) Sperry, D.G. and Wassersug, R.J. : A proposed function for microridges on epithelial cells. Anat. Rec. 185:253-257, 1976.

28) Wassersug, R.J. and Johnson, R.K. : A remarkable pyloric caecum in the evermannellid genus Coccorella with notes on gut structure and function in alepisauroid fishes (Pisces, Myctophiformes). J. Zoo., Lond. 179:273-289, 1976.

29) Grossman, E.S. and Austin, J.C. : The ultrastructural response to loading of the oral mucosa of the vervet monkey. J. Periodontal Res. 18:474-482, 1983.

30) Andrews, P. M. : Microplicae: characteristic ridge-like folds of the plasmalemma. J. Cell Biol. 68: 420-429, 1976.

31) Olson, K.R. and Fromm, P.O. : A scanning electron microscopic study of secondary lamellae and chloride cells of rainbow trout (Salmo gairdneri). $Z$. Zellforsch. $143: 439-449,1973$.

32) Iwasaki, S. and Miyata, K. : Studies on the lingual dorsal epithelium of the guinea pig by scanning 
electron microscopy. Okajimas Folia Anat. Jpn. 61: 423-436, 1985.

33) Uehara, K.. Miyoshi, M. and Miyoshi, S. : Actin filaments in microridges of the oral mucosal epithelium in the carp Cyprinus carpio. Cell Tissue Res.
$261: 419-422,1990$.

34) Uehara, K., Miyoshi, M. and Miyoshi, S. : Cytoskeleton in microridges of the oral mucosal epithelium in the carp, Cyprinus carpio. Anat. Rec. 230: 164-168, 1991. 